\title{
An overlooked population of the beira antelope Dorcatragus megalotis in Djibouti
}

The beira antelope Dorcatragus megalotis, which is listed as possibly extinct in Dibouti in the 1996 IUCN Red List, was observed there by the authors in 1993/94. The authors discuss its status in the country and the action needed for its conservation.

\section{Beira distribution and status}

From the available literature it is not clear whether or not the beira antelope Dorcatragus megalotis occurs in Djibouti (Table 1). Yalden et al. (1984) following Ansell (1971) described the species as being endemic to the north-east region of the Somali-arid zone. Their distribution map depicted the range as mainly in Somalia (Areas 1 and 1.1, Figure 1), and very marginally in Ethiopia, in the Marmar Mountains (Area 2, Figure 1), but not in Djibouti. Similarly, Simonetta (1988) mapped the beira's distribution as being along the entire length of the Somalia coast at the southern end of the Gulf of Aden, to the border with Ethiopia (Marmar Mountains) in the west, but not Djibouti. He added that the beira had a very patchy and local distribution in the mountains and arid stony hills of northern Somalia. He wrote of the status of the species that '...there was a marked decrease, at least locally, during the 1975 drought and numbers have not recovered.' The last published record of the beira in Ethiopia (Bolton, 1973) dates from an observation in 1972 south-east of Aysha in the Marmar Mountains (Area 2, Figure 1), where all other reliable Ethiopian records come from (Yalden et al., 1984).
In contrast to other authors, Simoneau (1974) reported that beira occurred throughout Djibouti, but particularly in the south. Kingdon (1989) mapped the distribution of the beira without references, but obviously in accordance with Maydon (1932), Yalden et al. (1984) and Simonetta (1988), plus an additional isolated occurrence in Djibouti along the northern coast of the Gulf of Tadjoura (Area 4, Figure 1). The distribution map of his more recent book (Kingdon, 1997), however, omits any occurrence of the beira in Djibouti.

Seal et al. (1990) included the species as 'Under Immediate Threat' while IUCN (1996) listed it as Vulnerable in Ethiopia and Somalia, but possibly extinct in Dijbouti.

\section{This study}

We report having seen the beira at two sites in Diibouti on three occasions in 1993 and 1994 (Table 2). Both sites were in the south-east of

Table 1. Occurrence of the beira in Djibouti according to different authors

\begin{tabular}{lll}
\hline Simoneau, & 1974 & Yes \\
Haltenorth and Diller, & 1977 & No \\
Dorst and Dandelot, & 1984 & No \\
Yalden et al., & 1984 & No \\
Burton and Pearson, & 1987 & No \\
Grzimek, & 1988 & Yes \\
Kingdon, & 1989 & Yes \\
Wilson and Reeder, & 1993 & Yes \\
IUCN, & 1996 & No? \\
Stuart and Stuart, & 1996 & No \\
Kingdon, & 1997 & No \\
\hline
\end{tabular}

Table 2. Record of the beira antelope in Diibouti, 1993 and 1994

\begin{tabular}{lllll}
\hline Date & Location & Grid reference & Altitude $(\mathrm{m})$ & No. individuals \\
\hline $30 / 04 / 93$ & Dadin Hill, near top & $1^{\circ} 01^{\prime} 00^{\prime \prime} \mathrm{N} 42^{\circ} 46^{\prime} 30^{\prime \prime} \mathrm{E}$ & c. 1000 & 3 \\
$13 / 05 / 93$ & Dadin Hill, near top & $11^{\circ} 06^{\prime} 00^{\prime \prime} \mathrm{N} 42^{\circ} 46^{\prime} 30^{\prime \prime} \mathrm{E}$ & c. 1000 & 6 \\
$28 / 01 / 94$ & Arrei Hill, near top & $1^{\circ} 05^{\prime} 30^{\prime \prime} \mathrm{N} 42^{\circ} 43^{\prime} 30^{\prime \prime} \mathrm{E}$ & c. 800 & 2 \\
\hline
\end{tabular}

(C) $1998 \mathrm{FFI}$, Oryx, 32 (1), 75-80 
the country between Ali Sabieh and Assamo, close to the borders with Ethiopia and Somalia (Area 3, Figure 1).

We were unable to gain much information about Area 4, which was mentioned as being within the beira's range by Kingdon (1989). This area was more or less closed to civilians between 1990 and 1996 because of conflict between different political groups in Djibouti. After the ratification of a peace agreement

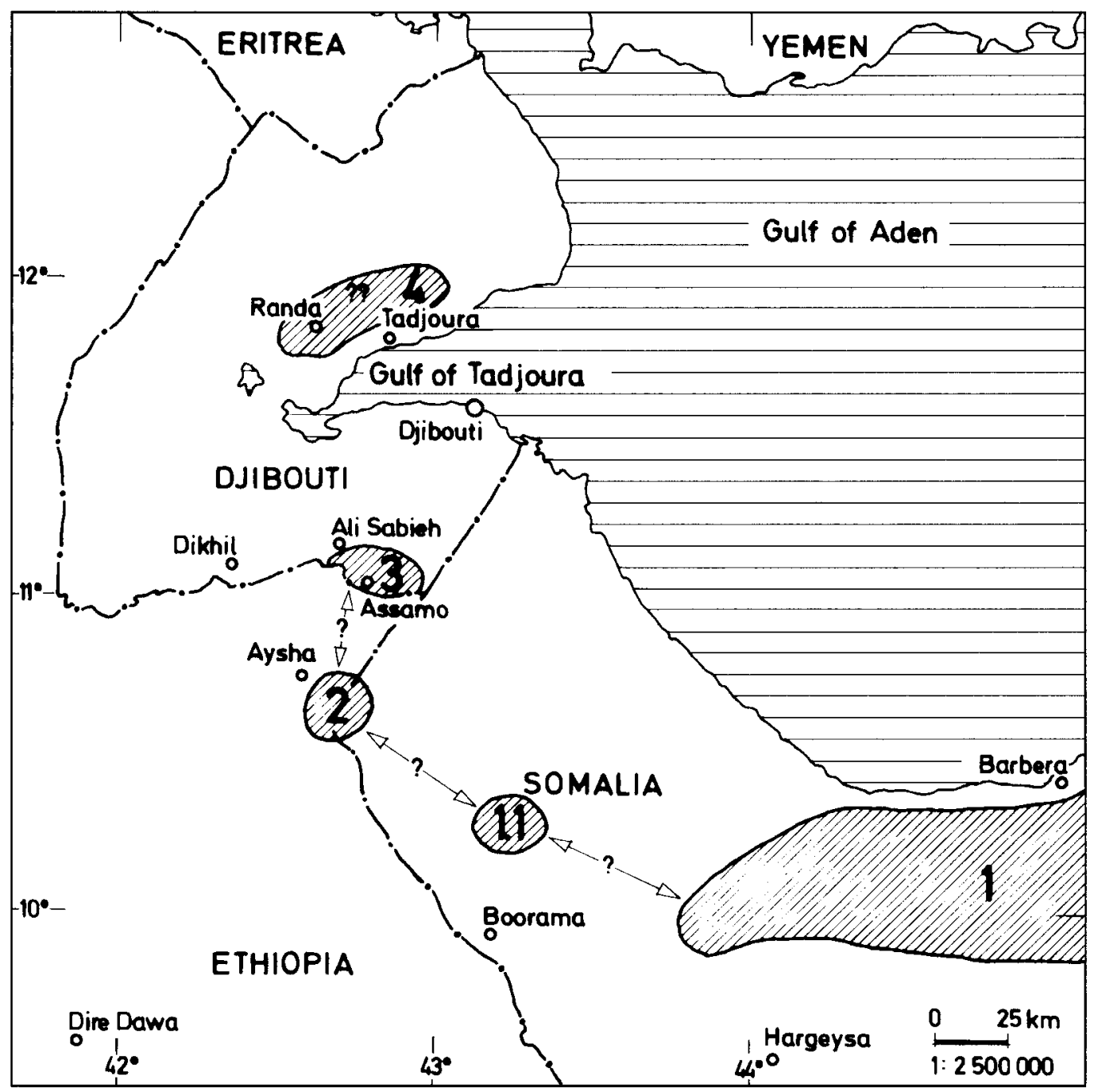

Figure 1. Map of beira occurrence.

1. Main occurrence, uninterrupted as far as the north-east corner of the Horn of Africa (Simonetta, 1988;

Kingdon, 1997).

1.1. Isolated (?) occurrence (Simonetta, 1988; Kingdon, 1997).

2. Isolated (?) occurrence (Bolton, 1973; Yalden et al., 1984).

3. Isolated (?) occurrence (this paper).

4. Isolated (?) occurrence (Kingdon, 1989).

? Probable contact between beira populations (this paper).

?? Uncertain occurrence (Kingdon, 1989). 


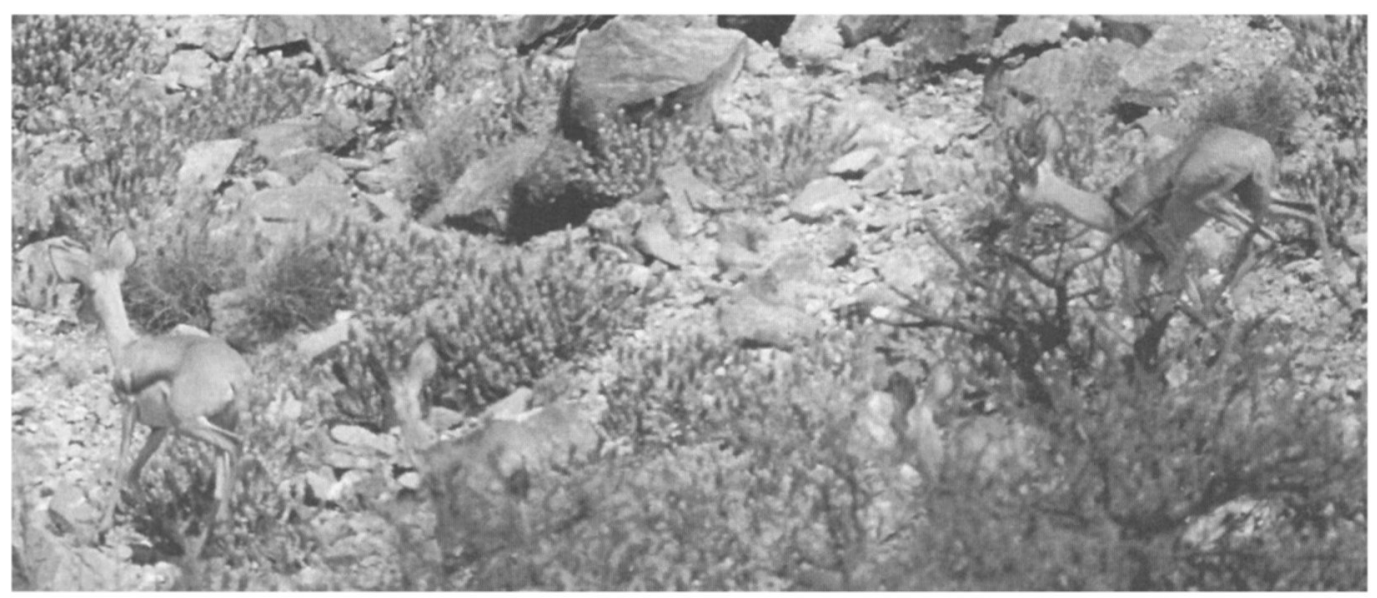

Dorcatragus megalotis, Djibouti 1994 (Thomas Künzel).

between the Government of Djibouti and the opposition, the situation is returning to normal and wildlife surveys should become possible in the future.

Area 4 contains the Forêt du Day, the only extensively wooded area in Djibouti. A franco- lin endemic to Djibouti Francolinus ochropectus occurs there, as well as a significant proportion of the world population of the threatened Bankouale palm Livingstonia carinensis (Welch and Welch, 1984, 1992; Welch et al., 1986). This palm was last seen and found in

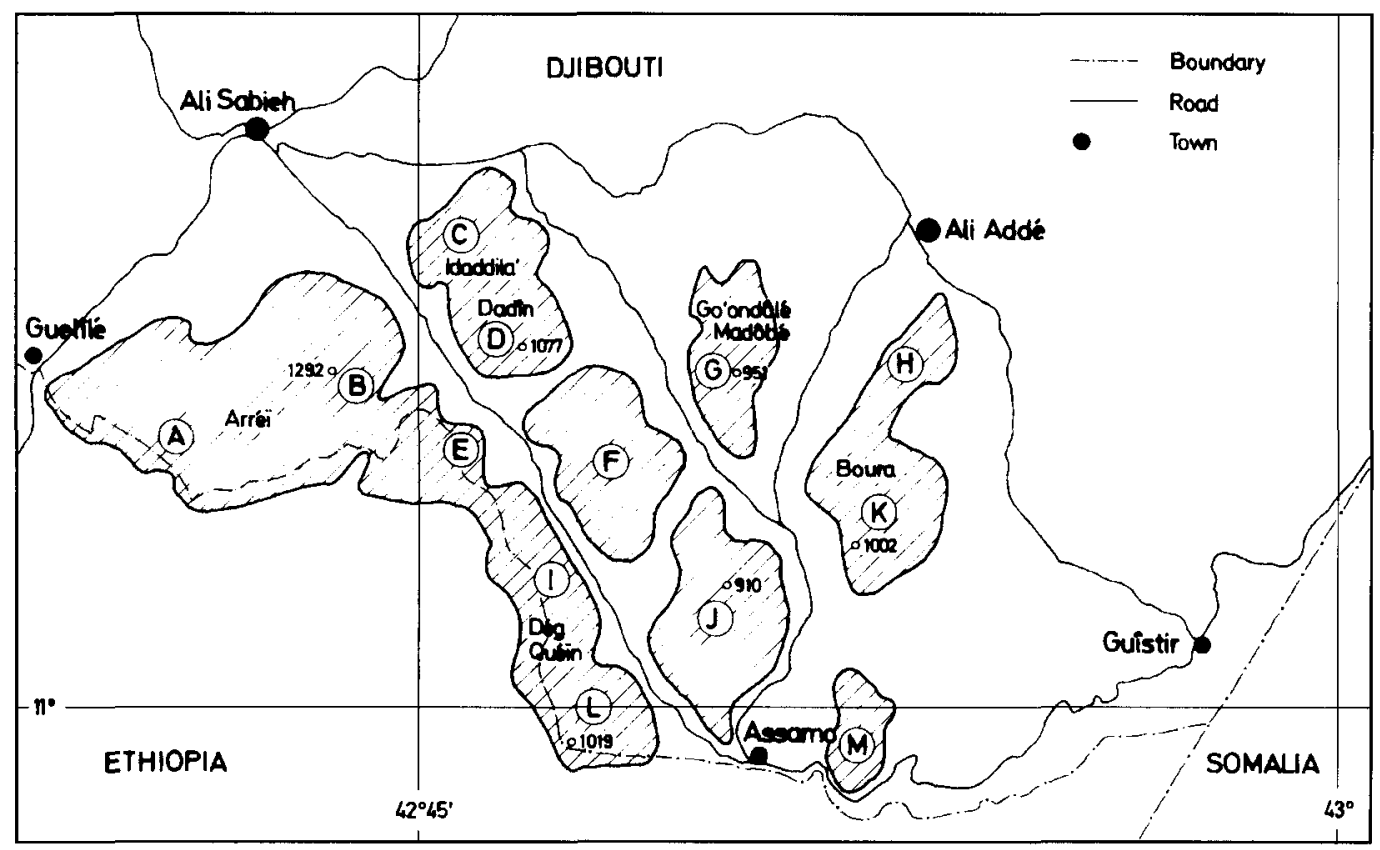

Figure 2. Detailed map of Area 3 (Figure 1), Altitudes are in metres. Hatched area, 600-1292 m, after Audru et al. (1987) covered by vegetation units M5 (and M4, Boura Hills).

$B, D$, authors' beira observation sites.

A, C, E-M, sites with possible occurrence of one group of beira each.

(C) $1998 \mathrm{FFI}$, Oryx, 32 (1), 75-80 
Table 3. Plants found at $900 \mathrm{~m}$ in authors' beira observation sites (after Audru et al., 1987)

\begin{tabular}{|c|c|}
\hline Family & Species \\
\hline Acanthaceae & $\begin{array}{l}\text { Ecbolium viride } \\
\text { Ruellia patula }\end{array}$ \\
\hline Andropogoneae & Cymbopogon schoenanthus \\
\hline Asclepiadaceae & $\begin{array}{l}\text { Caralluma priogonium } \\
\text { Caralluma sp. }\end{array}$ \\
\hline Asteraceae & $\begin{array}{l}\text { Launaea massauensis } \\
\text { Pulicaria somalensis }\end{array}$ \\
\hline Euphorbiaceae & Euphorbia triaculeata \\
\hline Lamiaceae & Orthosiphon pallidus \\
\hline Malvaceae & Abutilon fruticosum \\
\hline Mimosaceae & $\begin{array}{l}\text { Acacia etbaica uncinata } \\
\text { Acacia oerfota }\end{array}$ \\
\hline Polygalaceae & Polygala obtusissima \\
\hline Portulaceae & Portulaca quadrifida \\
\hline Scrophulariaceae & Campylanthus junceus \\
\hline Solanaceae & $\begin{array}{l}\text { Lycium shawii } \\
\text { Withania somnifera }\end{array}$ \\
\hline Tiliaceae & Grewia tenax \\
\hline Vitaceae & Cissus rotundifolia \\
\hline
\end{tabular}

reasonable condition by the authors in the wadi at Bankouale in 1995. In that year we had an opportunity to visit the Forêt du Day twice on official missions but we did not see any beira. Being primarily occupied with other project activities we could not spare much time searching for them. Even Welch and Welch (1984) in the course of their expedition in Djibouti, with special emphasis on the Forêt du Day, did not mention any beira records.

Area 4 has land that extends up to $c .1800 \mathrm{~m}$ and provides a large area of suitable habitat for beira. The Forêt du Day has been declared a national park by the Government of Djibouti but consequent action has not been implemented because of lack of funds (Anon., 1991) and overgrazing is a serious problem.

There is no information available on the home range or territory size of the beira to use as a basis for the estimation of the number of individuals that might occupy Area 3 . Kingdon (1982) plotted individual territory size against body mass for some antelopes with exclusive permanent territories. The beira's closest relatives (body weight 5-15 kg), Neotragus, Oreotragus and Madoqua have territory sizes of under 50 ha while Ourebia (12-20 kg body weight) has a territory size of 75-125 ha. Kingdon (1984) wrote, '... outside exceptionally well-favoured habitats exclusive permanent territories begin to lose viability once a territory holder weighs over $20 \mathrm{~kg}$.' This might also be the case for some species under $20 \mathrm{~kg}$ because Walther (1984) reported that Oreotragus oreotragus (average body weight 10-15 kg) in the Serengeti holds different territories according to season. This should be kept in mind when discussing the beira's territory/home range and planning population surveys. Nevertheless a beira group is believed to be intensely attached to its own hill or plateau (Kingdon, 1989).

Simonetta (1988) wrote that the beira 'is apparently a very selective feeder and its distribution may be related to that of its food plants'. Using vegetation cover we estimated the possible occurrence of beira around our two observation sites (Figure 2), where woody vegetation covers $1-20$ per cent and herbaceous vegetation fluctuates between 'scanty' in the dry season (July-August) to 20-40 per cent in the rainy season (October-April), according to Audru et al. (1987). The annual rainfall is $200-250 \mathrm{~mm}$. The type of vegetation at our observation sites is unit M5 of the class of vegetation found only in Djibouti's mountains and high plateaus and covering the entire region (500-1292 m) between Guelile, Ali Sabieh, Ali Adde and Assamo except the Boura hills, which is classified as unit M4 (Figure 2). (Audru et al., 1987; Table 3). These two vegetation units, which are characterized by Audru et al. (1987) as 'steppe arboree Acacia etbaica uncinata', are otherwise only found in Area 4.

A preliminary minimum estimate of the number of beira in Area 3 could be calculated using the following assumptions: (i) a group of beira contains four animals (average group size from our three observations); (ii) the distance between two groups of beira is $4 \mathrm{~km}$ (distance between our two observation sites); and (iii) each group of beira occupies one hill covered by vegetation units M4 or M5. As shown in Figure 2, this estimate results in 13 potential beira sites, giving a total number of 
c. 52 beira in Area 3. However, this is no more than a preliminary guess.

\section{Conservation}

The status of the beira in Djibouti is still far from clear but our observations suggest that they are able to live in hills also occupied by herdsmen and their goats. The law prohibits hunting, which is generally observed: in our 4year stay in the country we did not hear of any infringements. Thus, it is possible that beira could still survive in Area 4, and this should be checked by a survey.

We believe that the beira population in Djibouti may not be isolated because the Marmar Mountains in Ethiopia, where beira were seen in 1972 (Bolton, 1973), is only c. 50 $\mathrm{km}$ distant. The fact that there are no beira records from Ethiopia since 1972 is probably a result of the scarcity of experienced observers rather than local extinction. Beira are difficult to find, as Maydon (1932) recorded: "They were the hardest animal I have yet met to keep in view, and always seemed to fade away from sight... partly owing to the coloration and partly to their constant movement in and out of cover. When they stood motionless, even in the open, they were harder to see than ever, due to light and shade.' Hunting was permitted in Ethiopia until 1993 then banned by the government for a short period until the ban was lifted in 1996 (Anon., 1997), so any remaining beira in Ethiopia are threatened by hunting. In Somalia the situation is even worse for wildlife because of the long war.

Except for the ban on hunting in Djibouti, there are no conservation measures anywhere in the beira's range. We recommend that this be remedied, giving priority to Djibouti and the adjacent part of Ethiopia, including the Marmar Mountains. To be realistic the funds for these beira conservation measures would need to come from international conservation and donor agencies. Political security and the hunting ban would make Djibouti the most practical centre for research and conservation of beira and other wildlife. The concept of 'target species', (Vogel et al., 1996) would be a reasonable basis for beira conservation; the species fits the concept's species selection criteria because of: (i) the high degree of threat ; (ii) the high chance of survival given appropriate conservation activity; (ii) benefits to other species; and (iv) its potential popularity as a flagship species.

The first stage of a beira conservation action plan should include the measures listed below, which should be implemented without delay. The first three would cost little.

1 Reintroduction of the game-hunting ban in Ethiopia for the Marmar Mountains and the corridor connecting these mountains with Area 3 in Djibouti.

2 Discussing the conservation proposals with the Djibouti authorities and other groups - the people living in and owning the land of the relevant regions, and formulating a joint plan. 3 Investigation of the socio-ecological situation between beira and domestic goats that have occupied the same ecosystem for centuries, but noting that traditional goat-herding would not appear to jeopardize the survival of beira.

4 Establishing a national Wildlife Heritage Education Centre within the existing Centre for Tourism in Djibouti.

5 Establishment of a Beira Research/Captive Breeding Centre within the Direction de l'Elevage et des Peches in Djibouti in co-operation with the Conservation Breeding Specialist Group of IUCN.

6 A beira population survey in selected areas of Djibouti, Ethiopia and Somalia.

7 A population viability analysis.

As an indication of the potential positive effects of beira conservation activities in Djibouti on other wildlife, we would like to draw attention to the fact that Djibouti has stable populations of Gazella soemmeringi and G. dorcas pelzelni (authors' observations, Djibouti, 1992-96). Both are listed as Vulnerable by IUCN (1996).

The future existence of the beira in its overall distribution range certainly cannot be taken for granted. It is impossible to discover what the situation is in Somalia. But with a relatively small effort it should be possible to gain accurate information on the real situation of 
the beira population(s)/metapopulation in Djibouti and Ethiopia and to implement appropriate measures to safeguard this rare and beautiful endemic antelope.

\section{Acknowledgements}

The authors are very grateful to A. W. Gentry (Natural History Museum, London), C. P. Groves (Australian National University), D. Kock (Naturkundemuseum Senckenberg, Frankfurt) and D. W. Yalden (School of Biological Sciences, manchester) for providing diverse literature, giving helpful information and confirming the identification of the species photographed in Djibouti by the authors. Special thanks go to Dr M. A. Kamil (Directeur de la Direction d l'Elevage et des Peches, Djibouti) and A. Darar (Chef de Division des Peche, Djibouti), which supported privately and officially the author's activities in Djibouti. The observations were made possible by a long-term assignment of the authors in Djibouti with a fisheries development project sponsored by the German Agency for Technical Co-operation (GTZ).

\section{References}

Anon. 1991. Rapport National Environnement. Djibouti 91. Document elabore pour la Conference des NationsUnies sur l'Environnement et le Developpement (CNUED 92). Secretariat Technique du Comité National pour l'Environnement ONTA/SPSE.

Anon. 1997. Hunting resumes in Ethiopia. Oryx, 31 (1), 17 .

Ansell, W.F.H. 1971. Order Artiodactyla (excluding Gazella). In The Mammals of Africa: an Identification Manual. Part 15 (eds J. Meester and H. W. Setzer), pp. 1-84. Smithsonian Institution Press, Washington.

Audru, J., Cesar, J. Forgiarini, G. and Lebru, J.P. 1987. La Vegetation et les Potentiales Pastorales de la Republique de Djibouti. Institut d'Elevage et de Medicine vétérinaire des Pays Tropicaux, Paris.

Bolton, M. 1973. Notes on the current status and distribution of some large mammals in Ethiopia (excluding Eritrea). Mammalia, 37 (4), 562-582.

Burton, J.A. and Pearson, B. 1987. Collins Guide to the Rare Mammals of the World. W. Collins Sons \& Co. Ltd, London.

Dorst, J. and Dandelot, P. 1984. A Field Guide to the Larger Mammals of Africa. Collins, London.

Grzimek, B. (ed.). 1988. Grzimek's Enzyklopädie Säugetiere, Bd. 5. Kindler Vlg. GmbH, München.

Haltenorth, Th. and Diller, H. 1977. Mammiferes d'Afrique et de Madagascar. Delachaux and Niestle SA, Neuchatel, Switzerland.
IUCN. 1996. 1996 IUCN Red List of Threatened Animals. IUCN, Gland, Switzerland.

Kingdon, J. 1982. East African Mammals Vol. 3. Bovids. Academic Press, New York.

Kingdon, J. 1989. Island Africa-the Evolution of Africa's Rare Animals and Plants. Princeton University Press, New Jersey.

Kingdon, J. 1997. The Kingdon Field Guide to African Mammals. Academic Press, London.

Maydon, H.C. (ed.). 1932. Big Game Shooting in Africa. Seeley, Service and Co., London.

Seal, U.S., Sausman, K. and Mikolai, J. 1990. Aridland Antelope Workshop of the Captive Breeding Specialist Group of IUCN. San Antonio, Texas, USA, 13-15 September 1989.

Simoneau, E.-L. 1974. Les Animaux du Territoire Francais des Afars et des Issas. Copyright: E.-L. Simoneau, Djibouti.

Simonetta, A.M. 1988. Somalia. In Antelope Global Survey and Regional Action Plans. Part 1. East and Northeast Africa (ed. R. East), pp. 33-52. IUCN, Gland, Switzerland.

Stuart, C. and Stuart, T. 1996. Africa's Vanishing Wildlife. Swan Hill Press, England.

Vogel, K., Vogel, B., Rothhaupt, G. and Gottschalk, E. 1996. Einsatz von Zielarten im Naturschutz. Naturschutz und Landschaftsplanung, 28 (6), 179184.

Walther, F.R. 1984. Communication and Expression in Hoofed Mammals. Indiana University Press, Bloomington.

Welch, G.R. and Welch, H.J. 1984. Diibouti Expedition March 1984 - a Preliminary Survey of Francolinus ochropectus and the Birdlife of the Country. Privately published.

Welch, G.R., Welch, H.J., Coghlan, S.M. and Denton, M.L. 1986. Djibouti II - Autumn' '85. Privately published.

Welch, G.R. and Welch, H.J. 1992. Djibouti IIIMigrant Raptor Count. Minsmere Reserve, Saxmundham, UK.

Wilson, D.E. and Reeder, D.M. (eds). 1993. Mammal Species of the World: a Taxonomic and Geographic Reference. 2nd edn. Smithsonian Institution Press, Washington, DC.

Yalden, D.W., Largen, M.J. and Kock, D. 1984. Catalogue of the Mammals of Ethiopia. 5. Artiodactyla. Monitore Zooolgico Italiano (Nuova Serie) Supplemento, 19, 67-221.

\section{Th. Künzel and S. Künzel \\ Schrevenborner Weg 28 24226 Heikendorf, Germany}

Received 20 May 1997

Accepted 19 September 1997 